\title{
Production of transgenic piglets using ICSI-sperm-mediated gene transfer in combination with recombinase RecA
}

\author{
Francisco A García-Vázquez ${ }^{1}$, Salvador Ruiz ${ }^{1}$, Carmen Matás ${ }^{1}$, M José Izquierdo-Rico ${ }^{2}$, \\ Luis A Grullón ${ }^{1}$, Aitor De Ondiz , Luis Vieira ${ }^{1}$, Karen Avilés-López \\ Alfonso Gutiérrez-Adán ${ }^{3}$ and Joaquín Gadea ${ }^{1}$ \\ ${ }^{1}$ Departamento de Fisiología, Facultad de Veterinaria and ${ }^{2}$ Departmento de Biología Celular e Histología, Facultad de \\ Medicina, Universidad de Murcia, 30100 Murcia, Spain and ${ }^{3}$ Departamento de Reproducción Animal, INIA, 28040 \\ Madrid, Spain
}

Correspondence should be addressed to FA Garcia-Vazquez; Email: fagarcia@um.es

\begin{abstract}
Sperm-mediated gene transfer (SMGT) is a method for the production of transgenic animals based on the intrinsic ability of sperm cells to bind and internalize exogenous DNA molecules and to transfer them into the oocyte at fertilization. Recombinase-A (RecA) proteincoated exogenous DNA has been used previously in pronuclear injection systems increasing integration into goat and pig genomes. However, there are no data regarding transgene expression after ICSI. Here, we set out to investigate whether the expression of transgenic DNA in porcine embryos is improved by recombinase-mediated DNA transfer and if it is possible to generate transgenic animals using this methodology. Different factors which could affect the performance of this transgenic methodology were analyzed by studying 1) the effect of the presence of exogenous DNA and RecA protein on boar sperm functionality; 2) the effect of recombinase RecA on in vitro enhanced green fluorescent protein (EGFP)-expressing embryos produced by ICSI or IVF; and 3) the efficiency of generation of transgenic piglets by RecA-mediated ICSI. Our results suggested that 1) the presence of exogenous DNA and RecA-DNA complexes at $5 \mu \mathrm{g} / \mathrm{ml}$ did not affect sperm functionality in terms of motility, viability, membrane lipid disorder, or reactive oxygen species generation; 2) EGFP-expressing embryos were obtained with a high efficiency using the SMGT-ICSI technique in combination with recombinase; however, the use of IVF system did not result in any fluorescent embryos; and 3) transgenic piglets were produced by this methodology. To our knowledge, this is the first time that transgenic pigs have been produced by ICSI-SGMT and a recombinase.

Reproduction (2010) $\mathbf{1 4 0} 259-272$
\end{abstract}

\section{Introduction}

Transgenesis is a powerful biotechnological tool for the generation of genetically modified animals with applications in such different areas as veterinary medicine, biomedicine, and agriculture. DNA pronuclear microinjection has been the most popular system to generate transgenic animals. Transgenic mice, sheep, pigs, and cattle have been successfully produced using this technique. However, besides being expensive, this technique is still inefficient when it is used to generate transgenic farm animals (0.5-4\%; Niemann \& Kues 2000, Nakanishi et al. 2002, Wall 2002). Different methodologies have been developed to improve the efficiency of generation of transgenic pigs over the last decade and a half (reviewed by Gadea \& Garcia-Vazquez (2010a)). These include infection with retroviral vector (Whitelaw et al. 2004), nuclear transfer with modified somatic cells (Lai et al. 2002), and spermmediated gene transfer (SMGT; Lavitrano et al. 2002).
The first report showing that exogenous DNA could be introduced into sperm was provided by Brackett's group in rabbits (Brackett et al. 1971). Lavitrano et al. (1989) described a new method for transgenic animal production: SMGT. This method is based on the ability of sperm to bind, internalize, and transport exogenous DNA into an oocyte during fertilization (Francolini et al. 1993, Zani et al. 1995, Lavitrano et al. 1997). SMGT has been used more or less successfully in the production of transgenic embryos and animals in a large number of species (reviewed in Smith \& Spadafora (2005)).

Although transgenic animals have been obtained using SMGT, its efficiency is still low, mainly due to the spermatozoon's low uptake of exogenous DNA, thereby reducing the number of fertilized oocytes with transfected spermatozoa (Anzar \& Buhr 2006). In addition, inter- and intra-species success variability is still an unsolved problem associated with this technology. Other studies have used 'augmentation' techniques, such as electroporation or liposomes, to 'force' sperm to capture 
transgenes (Lai et al. 2001). More recent studies have introduced transgenes directly into the reproductive tract of male animals in what is known as testis-mediated gene transfer (Celebi et al. 2003, Coward et al. 2007).

Another innovation in SMGT has been the use of ICSI to deliver transgene-containing sperm cells directly into the egg, a process known as 'ICSI-mediated transgenesis' (ICSI-Tr) which was reported for the first time in mice (Perry et al. 1999) and later developed in pigs (Lai et al. 2001, Pereyra-Bonnet et al. 2008, García-Vázquez et al. 2009, Wu et al. 2009). These techniques (pronuclear injection and ICSI) are considered as passive methods for transgenesis (Shinohara et al. 2007), which rely on the repair mechanisms of the host for transgene insertion. In 'active transgenesis', recombinases or transposases are injected into oocytes to increase the efficiency of transgene integration into the genome (Shinohara et al. 2007).

In the mouse, both the bacterial recombinase protein recombinase-A (RecA; Kaneko et al. 2005, Moreira et al. 2007) and a mutated hyperactive Tn5 transposase protein (*Tn5p; Suganuma et al. 2005) increase transgenesis several fold as compared with conventional methods such as pronuclear microinjection (Nakanishi et al. 2002) and traditional ICSI-Tr (Perry et al. 1999). The RecA protein from Escherichia coli is one of the best characterized of the recombinases, and plays an important role in homologous recombination and DNA repair in E. coli (Kowalczykowski \& Eggleston 1994, Shinohara \& Ogawa 1995). It initiates pairing by binding to single-stranded DNA (ssDNA) and by forming a helical nucleoprotein presynaptic filament. RecA was shown to protect ssDNA from degradation by creating a protective coating through its binding to the latter (Chow et al. 1986). Such a protective mechanism has also been suggested to influence ssDNA stability during pronuclear microinjection-mediated transgenesis with RecA:ssDNA complexes during pig and goat transgenesis attempts (Maga 2001, Maga et al. 2003). This RecA coating of ssDNA resulted in higher embryo survival and transgene integration frequencies. Moreira et al. (2007) have used RecA in mouse SMGT-ICSI system, and they observed that RecA-complexed and non-complexed enhanced green fluorescent protein (EGFP) DNA attaches differently to fresh sperm cells, and resulted in a higher level of embryo mosaicism.

The objective of this study was to investigate whether SMGT is improved by recombinase-mediated DNA transfer. Different factors which could affect the performance were analyzed by studying 1) the effect of the presence of exogenous DNA and RecA protein on boar sperm functionality; 2) the effect of RecA on in vitro EGFP-expressing embryo production by IVF and ICSI; and finally, 3) the evaluation of transgenic piglet production by ICSI-SMGT technique and RecA combination by embryo transfer.

\section{Results}

\section{Effect of the presence of exogenous DNA and RecA protein on boar sperm functionality}

In our first experiment, we evaluated the effect of fresh sperm cells co-incubated with ssDNA complexes with E. coli recombinase RecA on boar sperm functionality. For this evaluation, eight replicates were performed. Spermatozoa were incubated with linearized plasmid EGFP (DNA) or RecA-DNA complexes (40:1 or 40:3 protein:DNA w/w) at concentrations of $10^{8} \mathrm{cells} / \mathrm{ml}$ and 5-15 $\mu$ g DNA/ml. Sperm viability, membrane lipid disorder, reactive oxygen species (ROS) generation, and motion parameters were evaluated by flow cytometry and computer-assisted sperm analysis (CASA) for control (no DNA), dsDNA $(5 \mu \mathrm{g})$, RecA 5 $(5 \mu \mathrm{g})$, and RecA $15(15 \mu \mathrm{g})$ after $2 \mathrm{~h}$ of co-incubation.

Sperm viability was measured by propidium iodide (PI) staining, which was significantly reduced by the presence of RecA-DNA complexes at a high DNA concentration of $15 \mu \mathrm{g} / \mathrm{ml}$ (Fig. $1 \mathrm{a}, P<0.01$ ), but the presence of $5 \mu \mathrm{g} / \mathrm{ml}$ of DNA or RecA-DNA complexes did not significantly decrease the viability compared with the control. Exactly the same effect was observed when lipid membrane disorder and viability were simultaneously measured (stained by merocyanine 540 and Yo-Pro-1). The percentage of live cells with low lipid membrane disorder was significantly reduced in the presence of RecA-DNA $15 \mu \mathrm{g} / \mathrm{ml}$ complexes (Fig. 1b, $P<0.01$ ). However, ROS generation (measured by $2^{\prime}, 7^{\prime}$-diclorofluorescein diacetate) was not different in the different experimental groups (fluorescent units; Fig. 1c, $P=0.36$ ).

The motion parameters measured by CASA were affected by the presence of DNA and RecA-DNA complexes. There was a significant reduction in the percentage of progressive motile cells and the other motion parameters in the group RecA 15 compared with the other experimental groups (Table $1 ; P<0.01$ ). Progressive motility was not reduced in the DNA and RecA 5 group compared with the control. Indeed, sperm velocities (curvilinear velocity (VCL), straight line velocity (VSL), and average path velocity (VAP)) were increased in these groups (Table $1 ; P<0.05$ ) with the same pattern that was observed in the ROS generation data (Fig. 1c).

Once it was observed that $15 \mu \mathrm{g}$ of DNA had a detrimental effect, this condition was not used in further experiments.

\section{In vitro production of EGFP-expressing embryos by ICSI using spermatozoa incubated with DNA and RecA recombinase}

Spermatozoa were incubated with dsDNA or RecA:ssDNA complexes, and later injected into the in vitro matured (IVM) oocytes (a total of 248 oocytes 

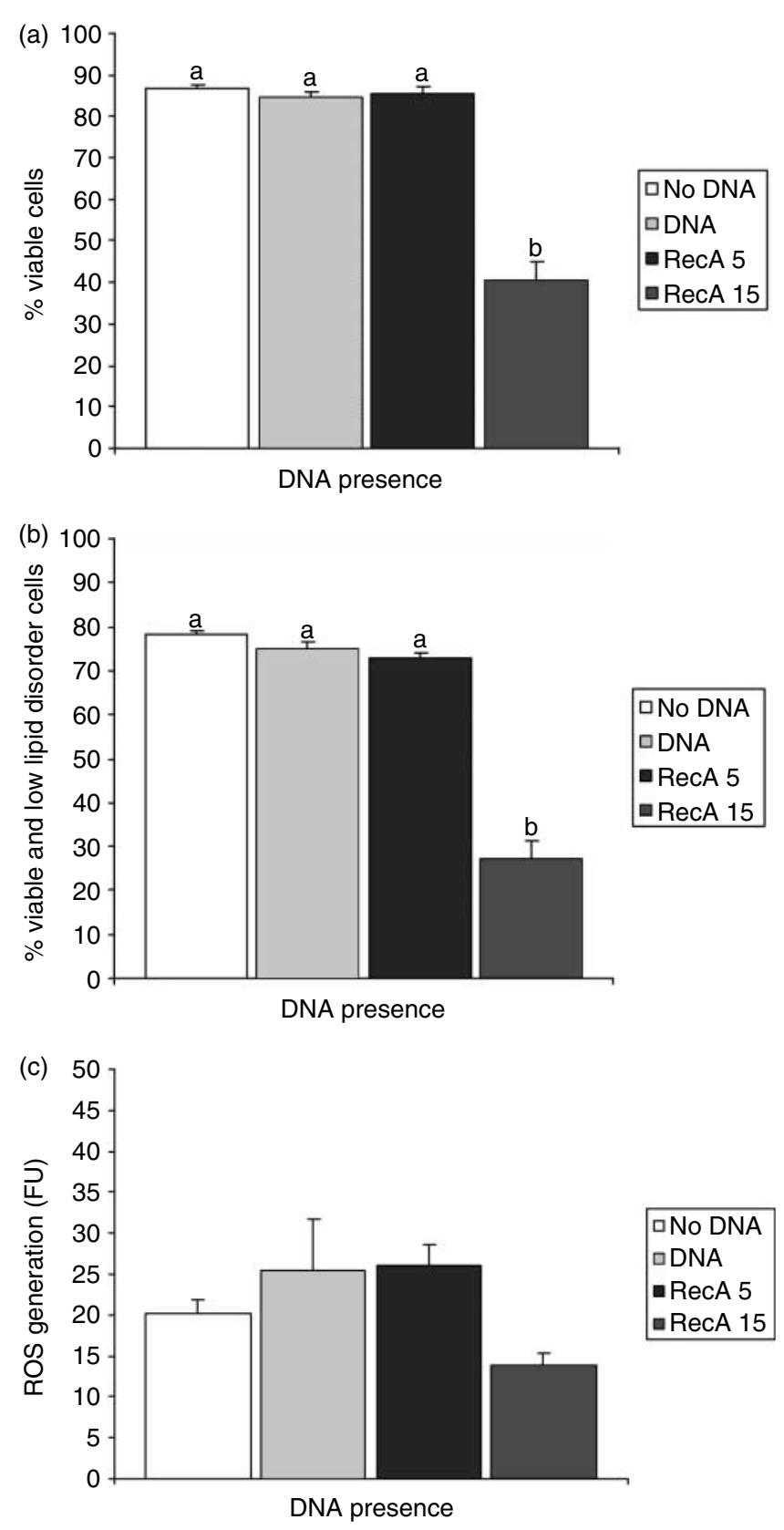

Figure 1 Effect of DNA incubation on (a) sperm viability $(P<0.01)$, (b) membrane lipid disorder $(P<0.01)$, and (c) ROS generation $(P=0.36)$. The spermatozoa were divided into different groups: no DNA group: no dsDNA incubation; DNA group: dsDNA incubation; RecA 5 and 15 groups: sperm incubation with ssDNA:RecA complex using 5 and $15 \mu \mathrm{g}$ of DNA respectively. ${ }^{\mathrm{a}, \mathrm{b}}$ Different letters indicate significant differences $(P<0.01)$.

were used in nine replicate experiments). Cleavage rate, blastocyst formation rate, number of cells per blastocyst, and rate of EGFP-expressing embryos were evaluated. Injection of fresh sperm with RecA:ssDNA complexes into MII oocytes resulted in fertilization and developmental rates comparable with those obtained by ICSI performed in the control group using fresh sperm incubated with dsDNA $(P>0.05$, Table 2). This result suggests that neither naked ssDNA nor RecA:ssDNA was deleterious to embryo survival at the concentrations used. However, the use of RecA:ssDNA complexes clearly increased the percentage of EGFP-expressing embryos in relation to the control group $(P<0.01)$. EGFP fluorescence was detected in $87.88 \%$ of embryos in the RecA group (in seven of the nine replicates, all the analyzed embryos expressed the protein) and $51.56 \%$ of embryos in the control group. This difference in EGFP expression was greater when only blastocysts were analyzed (28.6\% for control versus $83.3 \%$ for RecA group; Table 2, $P<0.01)$. Embryos-expressing EGFP are shown in Fig. 2.

\section{Evaluation of in vitro production of EGFP-expressing embryos by IVF using spermatozoa incubated with RecA recombinase}

A total of 584 in vitro-matured porcine oocytes were divided into three experimental groups (spermatozoa not incubated with DNA or incubated with dsDNA or RecA:ssDNA complexes) were used for this experiment. Co-incubation of the spermatozoa with dsDNA only induced a lower cleavage rate than in the RecA:ssDNA complexes group (41.2 vs $25.1 \%, P<0.01$, Table 3 ), and the control group (sperm not incubated with DNA) remained in a middle ranking position $(38.9 \%$, Table 3$)$. The production of blastocysts and the mean number of cells per blastocyst were similar in all experimental groups ( $P=0.59$ and $P=0.27$ respectively, Table 3 ). Finally, no EGFP-expressing embryos were obtained.

\section{Production of transgenic piglets}

\section{Pregnancy rates}

A total of 798 oocytes were injected with spermatozoa incubated with RecA:ssDNA complexes and immediately transferred into the oviducts of seven prepuberal crossbred sows. The results of the embryo transfer produced by ICSI-SMGT-RecA are reflected in Table 4 . The sows $D, E$, and $F$ were diagnosed as pregnant 25 days after the embryo transfer, a rate of pregnancy success of $42.8 \%$. A total of 15 piglets were born (five of them stillborn). The average weight of the litters was $1.1 \mathrm{~kg}$, and the pigs that were born alive did not show anatomical or physiological alterations, and had a normal growth.

\section{Transgene presence and expression}

Transgene presence was analyzed by means of PCR. The transgene was detected in seven of 15 animals (46.6\%), four of them were live animals (F1-F4) and three of them were dead animals (D6, D7, and E3; Table 4 and Fig. 3).

In four transgenic animals that were born alive, EGFP expression was analyzed in different tissues (liver, spleen, greater omentum, kidney, blood, adipose tissue, tail, and ear), as detailed in Table 5 and Fig. 4. 
Table 1 Motility parameters measured by computer-assisted sperm analysis. Boar spermatozoa incubated with dsDNA (DNA) or single-stranded DNA (ssDNA):recombinase-A (RecA) using 5 and $15 \mu \mathrm{g}$ of DNA respectively.

\begin{tabular}{|c|c|c|c|c|c|c|c|c|c|}
\hline Treatment & $\begin{array}{l}\text { \% Progressive } \\
\text { motility }\end{array}$ & VCL & VSL & VAP & LIN & STR & WOB & ALH & BCF \\
\hline No DNA & $46.7 \pm 1.2^{\mathrm{a}}$ & $97.5 \pm 1.8^{\mathrm{a}}$ & $35.3 \pm 0.8^{\mathrm{a}}$ & $59.9 \pm 1.4^{\mathrm{a}}$ & $35.9 \pm 0.5^{\mathrm{a}}$ & $58.9 \pm 0.5^{\mathrm{a}}$ & $60.7 \pm 0.7^{\mathrm{a}}$ & $3.9 \pm 0.1^{\mathrm{a}}$ & $6.7 \pm 0.1^{\mathrm{a}}$ \\
\hline DNA & $43.9 \pm 1.4^{\mathrm{a}}$ & $106.4 \pm 2.1^{b}$ & $38.9 \pm 1.0^{b}$ & $65.3 \pm 1.6^{\mathrm{b}}$ & $35.8 \pm 0.6^{a}$ & $58.6 \pm 0.8^{a}$ & $59.9 \pm 0.8^{a}$ & $4.2 \pm 0.1^{\mathrm{a}}$ & $6.7 \pm 0.1^{\mathrm{a}}$ \\
\hline RecA 5 & $46.8 \pm 1.7^{\mathrm{a}}$ & $109.7 \pm 1.9^{b}$ & $39.0 \pm 1.3^{\mathrm{b}}$ & $66.3 \pm 1.7^{b}$ & $35.4 \pm 0.8^{\mathrm{a}}$ & $58.4 \pm 0.9^{\mathrm{a}}$ & $60.2 \pm 0.8^{\mathrm{a}}$ & $4.2 \pm 0.1^{\mathrm{a}}$ & $6.3 \pm 0.2^{\mathrm{a}}$ \\
\hline $\operatorname{Rec} A 15$ & $20.3 \pm 3.1^{b}$ & $58.1 \pm 7.8^{\mathrm{c}}$ & $17.3 \pm 2.6^{\mathrm{c}}$ & $31.7 \pm 4.7^{c}$ & $22.9 \pm 3.2^{\mathrm{b}}$ & $42.7 \pm 5.6^{b}$ & $41.7 \pm 5.7^{b}$ & $3.0 \pm 0.5^{\mathrm{b}}$ & $4.1 \pm 0.5^{b}$ \\
\hline$P$ value & $<0.01$ & $<0.01$ & $<0.01$ & $<0.01$ & $<0.01$ & $<0.01$ & $<0.01$ & $<0.01$ & $<0.01$ \\
\hline
\end{tabular}

VCL, curvilinear velocity; VSL, straight line velocity; VAP, average path velocity; LIN, linearity of the curvilinear trajectory; STR, straightness; WOB, wobble (VAP/VCL); ALH, amplitude of lateral head displacement; BCF, beat cross frequency. ${ }^{a, b, c}$ Different superscripts in columns indicate significant differences $(P<0.05)$.

The presence of EGFP expression was confirmed in all tissues analyzed by western blot (Fig. 4). However, when we analyzed the tissues from the three stillborn animals generated, we observed differential EGFP expression (Table 6). From the animal E3, only one tissue sample analyzed (cartilage) was detected as expressing EGFP (expression in $8.3 \%$ of the tissues analyzed). On the other hand, the tissues from the piglet D6 (Table 6) showed the expression of EGFP in more than half of the samples (expression in $63.6 \%$ of the analyzed tissues), and in D7, EGFP expression was detected in $54.5 \%$ of tissues analyzed.

Using the same amount of sample in all the western blot analysis ( $15 \mu \mathrm{g}$ of protein per sample), the intensity of expression signals from the animal F1 was consistently weaker than from other animals (F2, F3, and F4), and the transgene signal distribution was less intensive in blood, adipose, tail, and ear than in other tissues (Table 5). Levels of EGFP expression in stillborn animals were the greatest in samples from liver, lung, and heart (Table 6).

Finally, we confirmed these results with an inmunohistochemistry study of different tissue samples (Fig. 5).

\section{Discussion}

In recent years, transgenic pigs have been indispensable in the field of biomedicine, with applications in several research areas (Petters \& Sommer 2000, Niemann et al. 2003, Prather et al. 2003, Gadea \& Garcia-Vazquez $2010 b$ ). Nevertheless, the pronuclear microinjection approach is not an efficient method for the production of transgenic pigs. However, in the mouse, ICSI-SMGT has been shown to be a valuable tool for the production of transgenic animals (Perry et al. 1999, Moreira et al. 2004, 2007). In pigs, ICSI efficiency is limited (García-Roselló et al. 2009), and the application of this transgenic technique has only been reported in a small number of studies (Smith \& Spadafora 2005). Recently, a new transgeneic model has been developed, in which ICSI-SMGT is combined with recombinase and transposase to increase the efficiency of the transmission of the exogenous gene. This technique has been denominated 'active transgenesis' (Shinohara et al. 2007). We investigated the possibility of exploiting the endogenous properties of recombinase proteins that allow them to associate with, bind, and recombine DNA, and their compatibility with IVF and ICSI-SMGT techniques, in order to generate transgenic pigs.

\section{Effect of the presence of exogenous DNA and RecA protein on boar sperm functionality}

Exogenous DNA concentration has been shown to affect transgenic efficiency by SMGT-ICSI in mice, rats, and pigs (Hirabayashi et al. 2005, Moreira et al. 2007, Wu et al. 2009). Although high concentrations of exogenous DNA increased the possibility of DNA uptake by spermatozoa, it also decreased sperm cell motility, viability, and fertilizing capacity (Lavitrano et al. 1989). Maione et al. (1997) also observed that high DNA concentrations induced strong nuclease activity in sperm cells, yielding not only cleavage of the foreign DNA, but also the degradation of sperm chromosomal DNA. Thus, a process resembling apoptosis is triggered in spermatozoa when increased concentrations of exogenous DNA are used for SMGT (Lanes et al. 2009).

Table 2 In vitro embryonic development of oocytes injected with recombinase-A (RecA) treated or fresh spermatozoa incubated with DNA and enhanced green fluorescent protein (EGFP)-expressing embryos.

\begin{tabular}{|c|c|c|c|c|c|c|c|c|}
\hline Sperm treatment & Complex & $\begin{array}{c}\text { No. of } \\
\text { oocytes } \\
\text { (replicates) }\end{array}$ & $\begin{array}{l}\text { Cleavage } \\
\text { rate }(\%)\end{array}$ & $\begin{array}{l}\text { Blastocyst } \\
\text { rate* }(\%)^{*}(\%)\end{array}$ & $\begin{array}{l}\text { No. of cells/ } \\
\text { blastocyst }\end{array}$ & $\begin{array}{l}\text { Total \% EGFP } \\
\text { expression* }\end{array}$ & $\begin{array}{l}\% \text { EGFP- } \\
\text { expressing } \\
\text { blastocysts }\end{array}$ & $\begin{array}{c}\text { Mosaicism } \\
\text { rate }(\%)\end{array}$ \\
\hline ICSI+fresh sperm & dsDNA & $117(9)$ & 54.7 & 10.9 & $43.3 \pm 9.9$ & $51.6^{\mathrm{a}}$ & $28.6^{\mathrm{a}}$ & 48.1 \\
\hline ICSI+fresh sperm & ssDNA+RecA & $131(9)$ & 50.4 & 18.2 & $37.6 \pm 5.7$ & $87.9^{b}$ & $83.3^{\mathrm{b}}$ & 39.6 \\
\hline$P$ value & & & 0.50 & 0.25 & 0.60 & $<0.01$ & $<0.01$ & 0.47 \\
\hline
\end{tabular}

${ }^{\mathrm{a}, \mathrm{b}}$ Different superscripts in columns indicate significant differences $(P<0.05)$.

"Related to cleaved embryos. 

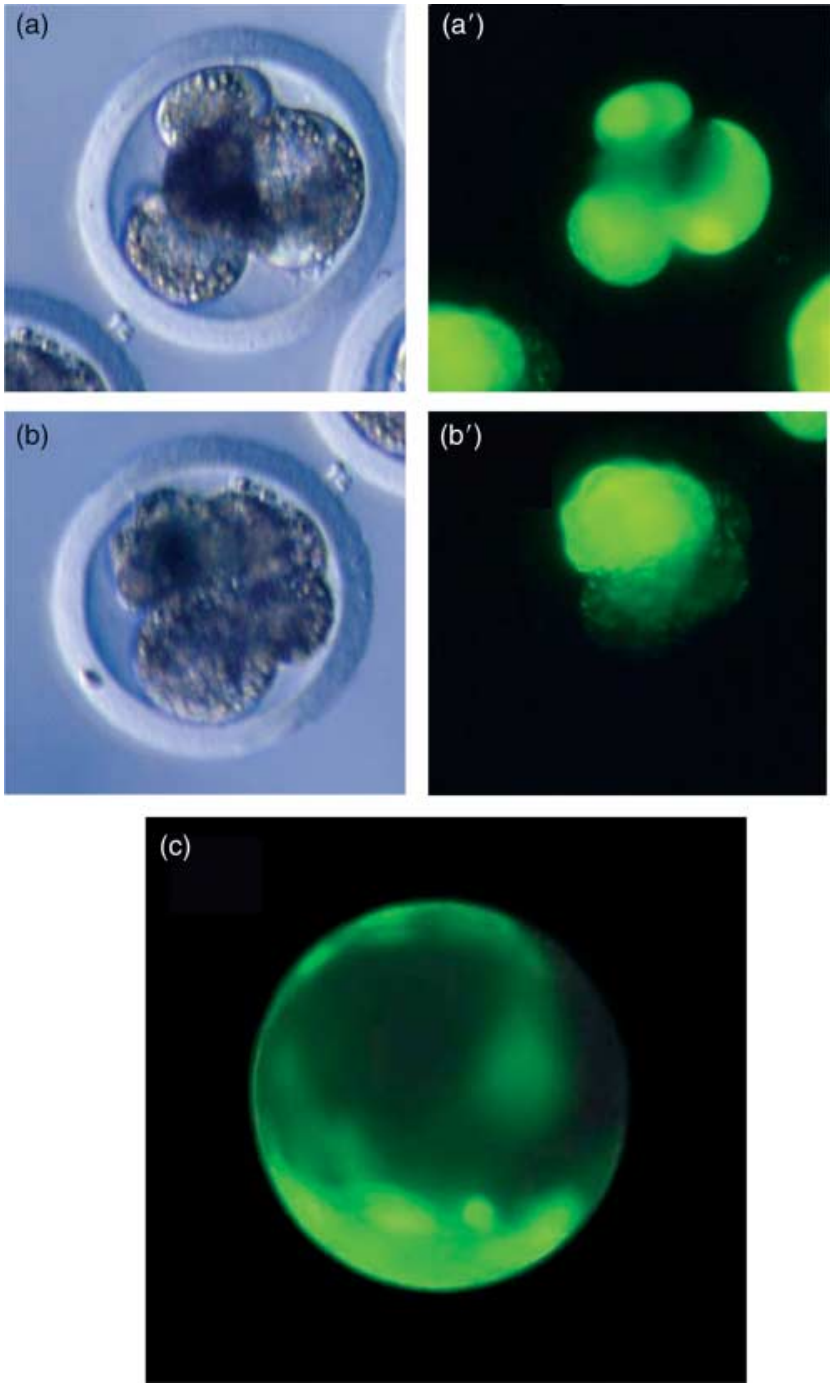

Figure 2 Porcine embryos expressing EGFP produced by injecting spermatozoa that had been coincubated with RecA:ssDNA. (a) and (b) four-cell embryos under bright light. $\left(a^{\prime}\right)$ and $\left(b^{\prime}\right)$ the same embryos shown under blue light. ( $\left.a^{\prime}\right)$ Total EGFP expression. $\left(b^{\prime}\right)$ Mosaic EGFP expression. (c) Blastocyst under blue light (original magnification $\times 200$ ).

In our experiments, sperm motility and viability were not affected by the presence of foreign DNA at a concentration of $5 \mu \mathrm{g} / \mathrm{ml}$ RecA-coated or -uncoated DNA. However, when $15 \mu \mathrm{g} / \mathrm{ml}$ of DNA were used in a RecA complex, the viability and motility significantly decreased. These results are in accordance with previous reports that confirmed that bovine and porcine spermatozoa can bind to exogenous DNA and maintain their motility (Rieth et al. 2000, Alderson et al. 2006, Kang et al. 2008). Interestingly, one previous report (Chan 2000) described how transfected sperm had even higher percentages of total motility and progression when compared with controls. However, some controversial aspects exist in relation to sperm motility, so in another report, transfected spermatozoa were reported to be immotile (Anzar \& Buhr 2006). The low viability and the absence of motility in spermatozoa bound with exogenous DNA could be associated with endonuclease activation (Maione et al. 1997, Spadafora 1998), which causes apoptosis-associated DNA cleavage and subsequent cell death (Anzar \& Buhr 2006).

In this study, no significant differences were found in ROS production in spermatozoa among experimental groups. ROS are known mostly for their detrimental effects on sperm functions (Twigg et al. 1998). Szczygiel et al. (2003) demonstrated that incubation of spermatozoa with exogenous DNA leads to breaks in paternal chromosomes, and it is well known that spermatozoa deficiency in nuclear DNA repair systems results in their increased susceptibility to oxidative stress and DNA fragmentation (De Lamirande et al. 1997).

\section{In vitro production of EGFP-expressing embryos by ICSI using spermatozoa treated with RecA recombinase}

Efficient ICSI-mediated gene transfer requires use of sperm with plasma membranes damaged by freezing and thawing or by a surfactant (Perry et al. 1999). Damage to the sperm plasma membranes causes DNA to associate with important consequences for the transfer of DNA into oocytes (Perry et al. 1999). However, sperm pretreatments that markedly disrupt the plasma membrane cause DNA fragmentation (Szczygiel et al. 2003), or can damage the sperm nucleus and lead to lower efficiency of embryogenesis following ICSI (Kurome et al. 2006, García-Vázquez et al. 2009). It is also commonly found that transgenes integrated by passive transgenesis commonly form long concatameric arrays (Suganuma et al. 2005). Such transgene loci are not desirable,

Table 3 In vitro embryonic development of oocytes IVF with recombinase-A (RecA) treated or fresh spermatozoa incubated with or without DNA and enhanced green fluorescent protein (EGFP)-expressing embryos.

\begin{tabular}{|c|c|c|c|c|c|c|}
\hline Sperm treatment & Complex & $\begin{array}{l}\text { No. of oocytes } \\
\text { (replicates) }\end{array}$ & $\begin{array}{l}\text { Cleavage } \\
\text { rate }(\%)\end{array}$ & $\begin{array}{l}\text { Blastocyst } \\
\text { rate }^{*}(\%)\end{array}$ & $\begin{array}{l}\text { No. of cells/ } \\
\text { blastocyst }\end{array}$ & $\%$ EGFP expression* \\
\hline IVF + fresh sperm & - & $59(4)$ & $38.9^{a, b}$ & 21.7 & $36.40 \pm 9.2$ & - \\
\hline IVF + fresh sperm & dsDNA & $382(4)$ & $25.1^{\mathrm{a}}$ & 21.8 & $37.26 \pm 3.3$ & 0 \\
\hline IVF + fresh sperm & $\operatorname{ssDNA}+\operatorname{Rec} A$ & $143(4)$ & $41.2^{\mathrm{b}}$ & 15.2 & $28.45 \pm 3.3$ & 0 \\
\hline$P$ value & & & $<0.01$ & 0.59 & 0.27 & \\
\hline
\end{tabular}

\footnotetext{
${ }^{\mathrm{a}, \mathrm{b}}$ In the same column indicate significant differences $(P<0.05)$.

${ }^{*}$ Related to cleaved embryos.
} 
Table 4 Production of piglets derived from ICSI-sperm-mediated gene transfer produced zygotes.

\begin{tabular}{|c|c|c|c|c|c|c|c|}
\hline Recipient & $\begin{array}{c}\text { Embryo } \\
\text { transferred }\end{array}$ & Pregnancy & Piglets & Status at delivery & Gender & $\begin{array}{l}\text { Weight at } \\
\text { delivery }(\mathrm{kg})\end{array}$ & PCR \\
\hline A & 102 & - & - & - & - & - & \\
\hline B & 102 & - & - & - & - & - & \\
\hline \multirow[t]{5}{*}{ C } & 95 & - & - & - & - & - & \\
\hline & & & $\# 1$ & Live & Female & 1.5 & - \\
\hline & & & $\# 2$ & Live & Female & 1.1 & - \\
\hline & & & $\# 3$ & Live & Female & 1.3 & - \\
\hline & & & $\# 4$ & Live & Male & 0.8 & - \\
\hline \multirow[t]{6}{*}{$\mathrm{D}$} & 113 & + & $\# 5$ & Live & Female & 1.1 & - \\
\hline & & & \#6 & Stillborn & Male & 1.2 & + \\
\hline & & & \#7 & Stillborn & Male & 1.0 & + \\
\hline & & & $\# 8$ & Stillborn & Female & 0.4 & - \\
\hline & & & & Total live: 5 & & Average: 1.05 & \\
\hline & & & $\# 1$ & Live & Female & 0.7 & - \\
\hline \multirow[t]{4}{*}{ E } & 119 & + & $\# 2$ & Stillborn & Male & 0.6 & - \\
\hline & & & $\# 3$ & $\begin{array}{l}\text { Stillborn } \\
\text { Total live: } 1\end{array}$ & Female & $\begin{array}{c}1.2 \\
\text { Average: } 0.8\end{array}$ & + \\
\hline & & & $\# 1$ & Live & Male & 1.4 & + \\
\hline & & & $\# 2$ & Live & Female & 1.8 & + \\
\hline \multirow[t]{3}{*}{$\mathrm{F}$} & 125 & + & $\# 3$ & Live & Female & 1.4 & + \\
\hline & & & $\# 4$ & Live & Male & 1.5 & + \\
\hline & & & & Total live: 4 & & Average: 1.5 & \\
\hline G & 142 & - & - & - & - & - & \\
\hline Total & & & & Total live: 10 & $\begin{array}{l}\text { Female: } 7 \\
\text { Male: } 3\end{array}$ & Average: 1.1 & Total: 7 \\
\hline
\end{tabular}

because they often have the potential to generate aberrant RNAs that can cause gene silencing (Garrick et al. 1998).

Thus, in our second experiment, the aim was to see whether the use of RecA exerts a protective effect on the chains of ssDNA, translating into an improvement in embryonic development and in the rate of production of EGFP-expressing embryos through ICSI, when the sperm was incubated with RecA:ssDNA complexes. The results confirmed that embryo development produced by ICSI was not affected by the use of RecA, but also that the use of RecA represented an improvement in the percentage of EGFP-expressing embryos produced ( 87.9 vs $51.6 \%$ ), confirming previous studies that reported that the use of recombinase RecA increased the efficiency of production of transgenic embryos using pronuclear microinjection in farm animals (Maga 2001, Maga et al. 2003) and ICSI in mice (Kaneko et al. 2005). The role of RecA in transgenesis could be the protection of ssDNA from degradation, as previously suggested for pronuclear injection of RecA:ssDNA complexes (Maga et al. 2003). This mechanism of protection has also been suggested to influence the stability of ssDNA during the transgenesis process using pronuclear microinjection with RecA:ssDNA complexes in pig and goat (Maga 2001, Maga et al. 2003). When ICSI-Tr is performed with live sperm cells, RecA may facilitate transgene integration, first by protecting the DNA from nucleases present in the sperm solution before sperm injection, and second by protecting it from the intracellular oocyte degradation that usually occurs in its absence (Moreira et al. 2007).
The EGFP fluorescence of embryos injected with RecA:ssDNA complexes demonstrates transgene stability, suggesting that RecA plays a different, possibly enzymatic, role in transgene integration (Kaneko et al. 2005).

\section{In vitro production of EGFP-expressing embryos by IVF using spermatozoa treated with RecA recombinase}

Porcine IVF with spermatozoa coincubated with exogenous RecA-coated and -uncoated DNA did not produce any EGFP-expressing embryos in our experimental conditions. Several researchers have investigated the use of porcine IVF-SMGT for transgenic embryo production, but none were successful in producing protein-expressing embryos (Horan et al. 1992, Lai et al. 2001, Bolling et al. 2003).
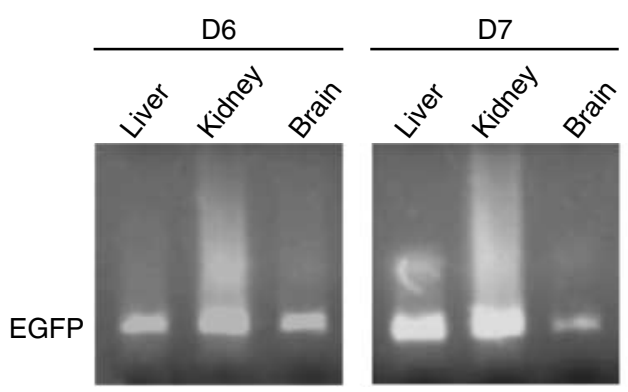

Control

$(+) \quad(-)$

Figure 3 PCR analysis of genomic DNA (liver, kidney, and brain) from D6 and D7 piglets. Positive control $(+)$ (genomic DNA from EGFP-transgenic mouse); negative control (genomic DNA from nontransgenic pig). 
Table 5 Enhanced green fluorescent protein-expressing tissues in F1, F2, F3, and F4 piglets.

\begin{tabular}{|c|c|c|c|c|c|c|c|c|}
\hline No. of piglet & $\mathbf{L i}$ & Sp & Om & Ki & BI & Ad & Ta & Ea \\
\hline $\begin{array}{l}\mathrm{F} 1 \\
\mathrm{~F} 2 \\
\mathrm{~F} 3 \\
\mathrm{~F} 4\end{array}$ & $\begin{array}{l}+ \\
+++ \\
+++ \\
++\end{array}$ & $\begin{array}{l}+ \\
++ \\
++ \\
+\end{array}$ & $\begin{array}{l}+ \\
++ \\
++ \\
+++\end{array}$ & $\begin{array}{l}+ \\
++ \\
++ \\
+++\end{array}$ & $\begin{array}{l}+ \\
+ \\
+ \\
+\end{array}$ & $\begin{array}{l}+ \\
+ \\
+ \\
+\end{array}$ & $\begin{array}{l}++ \\
+ \\
+ \\
+\end{array}$ & $\begin{array}{l}+ \\
+ \\
+ \\
+++\end{array}$ \\
\hline
\end{tabular}

$\mathrm{Li}$, liver; Sp, spleen; Om, greater omentum; Ki, kidney; Bl, blood; Ad, adipose; Ta, tail; Ea, ear. The evaluation was done using the following criteria: + , weakly positive; ++ , medium positive; +++ , strongly positive. The results are reported as lines intensity.

Chan et al. (2000a, 2000b) were not able to obtain any transgenic embryos using primate spermatozoa by IVF but were successful in obtaining transgenic embryos by ICSI. Nevertheless, limited success has been reported with bovine IVF-SMGT (Gagné et al. 1991, Sperandio et al. 1996, Rieth et al. 2000).

It has been previously reported that there is a window of opportunity, in which the exogenous DNA binds to spermatozoa, and it coincides with the early stage of capacitation (Lavitrano et al. 2002). It is possible that under our experimental conditions, sperm capacitation occurs very quickly, so that DNA binding can occur, but perhaps the acrosome reaction takes place too early and thus the spermatozoa die. In this case, changes in the sperm membrane functionality might modulate the time of DNA binding; the populations of viable sperm attached to the DNA may determine success or failure in the production of transgenic animals using this method. Under our experimental conditions, we have confirmed that the cells with the most DNA bound are the dead cells or the cells with severe membrane alterations in boar spermatozoa (García-Vázquez et al. 2009).

On the other hand, it is possible that the DNA binding induces the alteration and death of the cell by endonuclease activation in an apoptotic-like process (Anzar \& Buhr 2006). It has been suggested that mature spermatozoa contain nucleases that when induced by internalization of foreign DNA might cause degradation of both sperm chromosomal DNA and added exogenous DNA (Maione et al. 1997, Spadafora 1998, Szczygiel

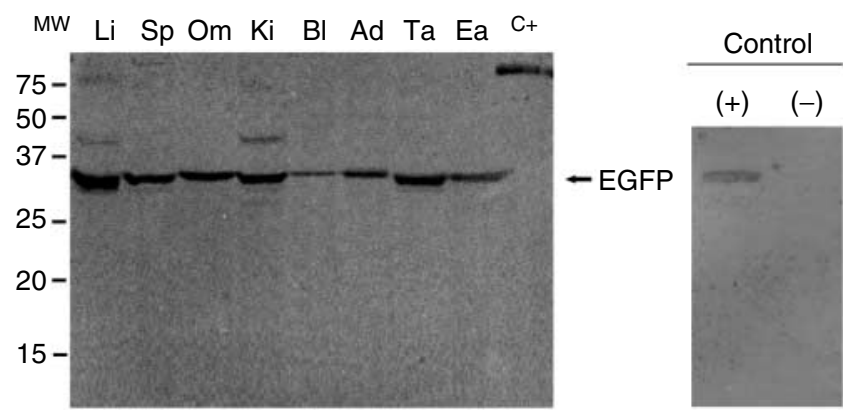

Figure 4 Expression analysis of EGFP genetic modified piglet by SDS-PAGE and western blot. Different tissues were studied (Li, liver; Sp, spleen; Om, greater omentum; $\mathrm{Ki}$, kidney; Bl, blood; Ad, adipose tissue; Ta, tail; Ea, ear; MW, molecular weight; $\mathrm{C}(-)$, wild-type control; $\mathrm{C}(+)$, mouse ZP3-GFPor EGFP-transgenic mouse) from F2 piglet generated with RecA:ssDNA. Sample from liver showed high levels of expression. et al. 2003). Such DNA degradation might decrease the possibility of a sperm carrying exogenous DNA and participating in fertilization (Kang et al. 2008). In line with this, the medium developed by Lavitrano et al. (2002) containing EDTA and free of $\mathrm{Ca}^{2+}$ allows the capacitation process to occur slowly. With this medium free of $\mathrm{Ca}^{2+}$, the probability that the endogenous endonucleases act on foreign DNA is reduced. However, calcium and bicarbonate ions are necessary for the sperm capacitation process in swine (Harrison 1997), and when the $\mathrm{Ca}^{2+}$ concentration in the media is increased, this has been shown to lead to an increase in penetration rate and in the mean number of sperm per penetrated oocyte (Abeydeera \& Day 1997). The IVF medium used in our experiments is TALP medium that contains high levels of $\mathrm{Ca}^{2+}$, which could induce the action of endonucleases on foreign DNA. Moreover, the capacitated sperm that can move freely within the cumulus matrix may bind to the surface membrane but not cross it (Myles \& Primakoff 1997). Moreover, Chan et al. (2000a, 2000b) showed that the signal of rhodamine-labeled plasmid-bound spermatozoa is lost at the oocyte surface during sperm interaction with the zona pellucida (ZP), but this is not the case with the ICSI technique. In IVF approaches, immediately after sperm penetration, the contents of cortical granules are secreted and the enzymes could modify the ZP in a process to prevent sperm penetration (Stein et al. 2004). These data suggest that both mechanical and enzymatic actions must be considered.

\section{Production of transgenic piglets by embryo transfer}

Using ICSI-Tr in mice, the transfection efficiency is on average, $2.5 \%$ of oocytes injected (OI) or $20 \%$ of animals born $(A B)$, with very low rates of mosaicism (Perry et al. 1999). Recently, a more efficient version of this method was reported where the efficiencies of OI and $A B$ were 4.6 and $45 \%$ respectively (Moreira et al. 2007). In pigs, previous reports have obtained transgenic piglets using SMGT-ICSI. Yong et al. (2006) transferred embryos produced by ICSI and spermatozoa from a transgenic boar (created by Cabot et al. (2001)) to six recipient females and obtained a transgenic pig, and Naruse et al. (2005) obtained a single transgenic pig after three embryo transfers. 
Table 6 Enhanced green fluorescent protein-expressing tissues in D6, D7, and E3 piglets.

\begin{tabular}{llllllllllll}
\hline No. of piglet & $\mathbf{L i}$ & $\mathbf{K i}$ & $\mathbf{B r}$ & $\mathbf{S k}$ & $\mathbf{S m}$ & $\mathbf{L u}$ & $\mathbf{H e}$ & Te/Ov & Sp & Di & $\mathbf{B v}$ \\
\hline D6 & + & ND & ++ & + & ++ & +++ & +++ & - & - & + & - \\
D7 & +++ & ++ & - & ++ & ++ & - & - & ND & - & ++ & ++ \\
E3 & - & - & - & - & - & - & - & - & - & - & - \\
\hline
\end{tabular}

Li, liver; Ki, kidney; Br, brain; Sk, skin; Sm, skeletal muscle; Lu, lung; He, hearth; Te/Ov, testicle/ovary; Sp, spleen; Di, digestive aparatous; Bv, blood vessels; $\mathrm{Ca}$, cartilage. The evaluation was done using the following criteria: + , weakly positive; ++ , medium positive; +++ , strongly positive; ND, not determined. The results are reported as lines intensity.

In our studies, after embryo transfer to seven receipt females, we obtained three pregnancies. Just a few research groups have been able to obtain piglets by ICSIderived embryos, and the success using ICSI with in vitro-matured oocytes is even more limited (reviewed by García-Roselló et al. (2009)). From 15 pigs born, seven were transgenic $(46.6 \%)$, with four of them (live piglets) with protein expression in all the tissues $(57.1 \%)$. In line with this, Kaneko et al. (2005) observed that all transgenic mice produced by RecA-ICSI were fully transgenic with all of them passing the trait to the next generation. Suganuma et al. (2005) observed similar facilitated transgene insertion during a transposase enzyme-mediated insertion of a transposon during ICSI microinjections as a complex named transposome (TN:ICSI). However, Moreira et al. (2007) found that although the transgenesis efficiency of the common ICSIbased transgenesis procedure with frozen-thawed sperm cells is similar to that of ICSI with fresh sperm cells and RecA-DNA complexes, the traditional ICSI-Tr procedure with frozen-thawed spermatozoa is much more efficient for maintaining a low frequency of founder animal mosaicism.

Three of the animals generated by this RecA:ssDNA complex approach had mosaic expression, suggesting a delayed integration of the transgene in the host genome after the first cell division (Kaneko et al. 2005, Moreira et al. 2007). Thus, Shinohara et al. (2007) affirmed that one of the problems of active transgenesis in mice is the high level of mosaicism. According to Chan et al. (1999), the process of integration in the embryos that express GFP in $100 \%$ of the blastomeres probably occurred in the first cellular cycle, the pronuclear state before the replication of the DNA. In the embryos that have 50\% of the cells expressing GFP, there are two possibilities: 1) the integration of transgenes occurred after the

\section{F1 piglet}

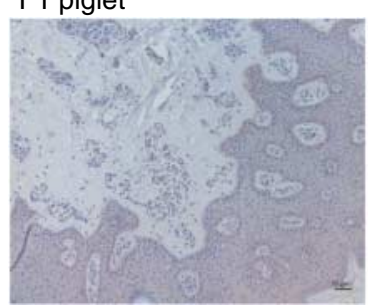

F4 piglet
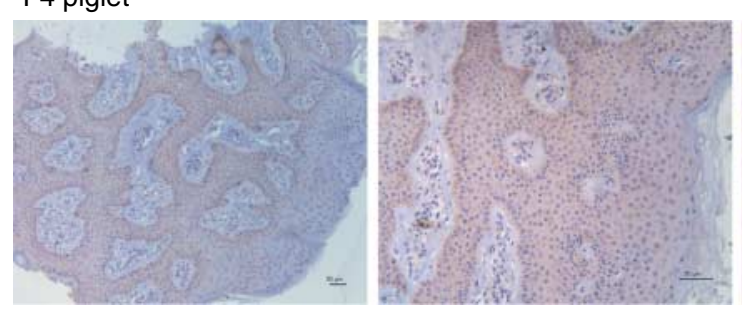

Negative control

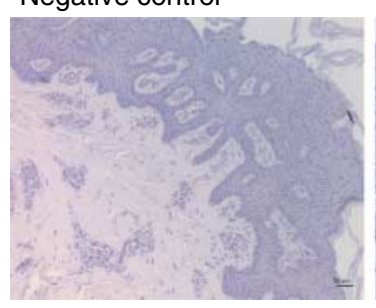

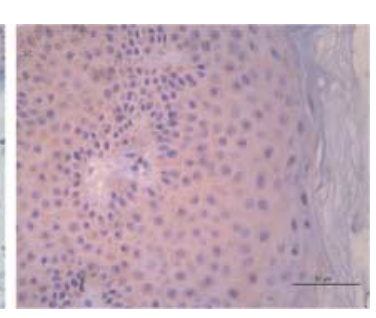
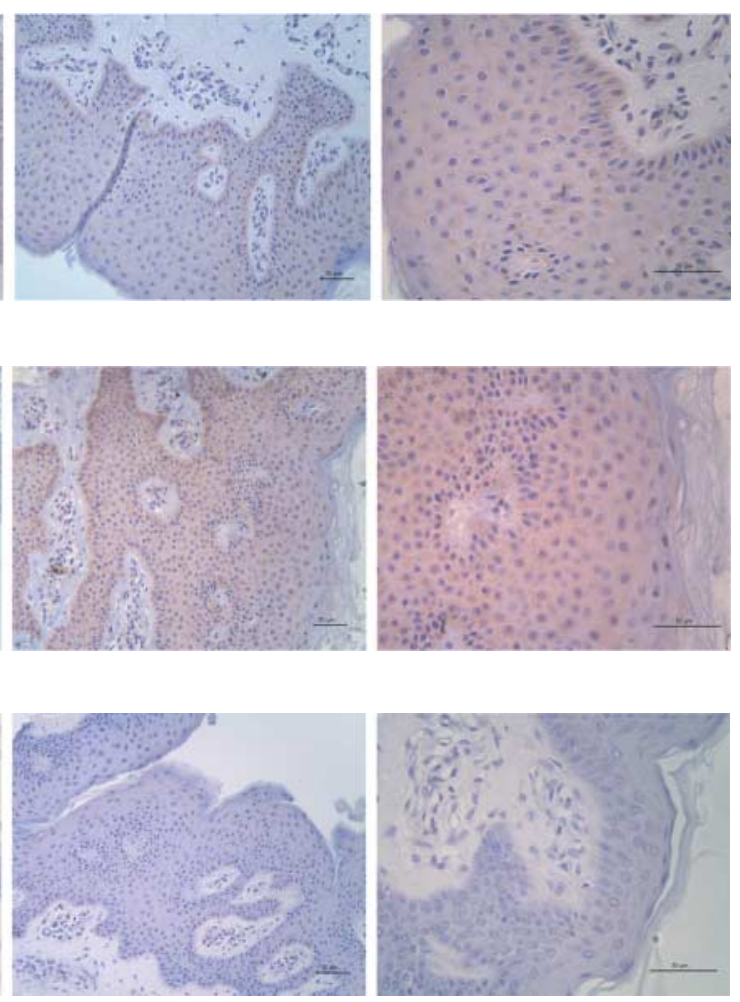

Figure 5 Inmunohystochemistry study of sections of skin from transgenic piglets (F1 and F4) using an anti-EGFP antibody and comparable tissue sections from a nontransgenic control piglet. Scale bars, $50 \mu \mathrm{m}$. 
replication of the DNA in the first cellular cycle; or 2) the integration occurred before the replication of the DNA in the second cellular cycle, at the two-cell stage. Similarly, an embryo that expresses GFP in $75 \%$ cells was probably derived from a combination of numerous integration events.

In the current study, five of the piglets were stillborn. In the ICSI technique, the manual selection of a spermatozoon and injection of the whole cell, complete with all acrosome and plasma membranes intact, result in abnormalities of sperm decondensation, retention of the acrosomal structures and proteins, and exclusion of the paternal nuclear centriole from the mitotic apparatus (Hewitson et al. 1999, Terada et al. 2000). These concerns have led to the predictions of chromosomal abnormalities and developmental defects that could cause the deaths of the animals. Techniques for the in vitro production of embryo are associated with a higher incidence of embryonic and fetal loss (Hyttel et al. 2000). In addition, three of these stillborn piglets were transgenic. Some authors have inferred that the presence of a great number of integrated copies of the transgene (Kaneko et al. 2005, Naruse et al. 2005) may affect the viability or functionality of some of the vital organs, for example, D6 in heart and lung, and D7 for liver and kidney, although the number of integrated transgene copies has not been analyzed in this study.

In the transgenic piglets born in our study, it was not possible to detect any direct fluorescence. Direct EGFP fluorescence detection is not the most sensitive indicator of EGFP expression. Undetectable direct EGFP fluorescence may be due to protein missfolding or to partial translocation of the peptide containing the recognized epitope (Chan et al. 2000a). Alternatively, the lack of visible fluorescence could also be due to low protein expression. The amount of the protein in the different tissues might not be enough to produce direct fluorescence. In other studies in which embryo fluorescence was undetectable by direct GFP imaging, when the embryo was labeled with an anti-GFP antibody, a fluorescence signal was detected under a microscope (Chan et al. 2000b).

The exact mechanism by which RecA may facilitate random transgene integration is not clear. The RecA protein may also act by protecting the DNA from degradation by cellular enzymes, thereby increasing the half-life of the DNA probes resulting in increased associations with the genome for a greater chance of producing a transgenic animal. The protection offered by RecA may also increase the probability that the transgene integrates after the one-cell stage. Another possibility is that the transgene DNA is directed into the genome through the use of a microhomology search (Kaneko et al. 2005). Such a mechanism has been described in the case of integration of Agrobacterium tumefaciens T-DNA into the host plant genome (Valentine 2003). The use of a RecA mutant that retains its ssDNA-binding properties but is deficient in strand exchange activity (Cazaux et al. 1998) may shed light on the role of RecA in the transgenesis process (Kaneko et al. 2005).

In summary, the use of a system of ICSI-SMGT using IVM oocytes and spermatozoa incubated with RecA:ssDNA complexes is a viable methodology to successfully produce transgenic piglets, and opens the way for the production of new transgenic pig models.

\section{Materials and Methods \\ Ethics}

This study was developed following institutional approval from the University of Murcia, and it was performed in accordance with the Animal Welfare regulations of that institution.

\section{Material}

\section{Media and chemicals}

Unless otherwise indicated, all chemicals and reagents were purchased from Sigma-Aldrich Química S.A. The oocyte maturation medium was NCSU-37 supplemented with $0.57 \mathrm{mM}$ cysteine, $1 \mathrm{mM}$ dibutyryl cAMP, $5 \mu \mathrm{g} / \mathrm{ml}$ insulin, $50 \mu \mathrm{M} \beta$-mercaptoethanol, $10 \mathrm{IU} / \mathrm{ml}$ equine chorionic gonadotropin (eCG; Folligon, Intervet International B.V., Boxmeer, Holland), $10 \mathrm{IU} / \mathrm{ml}$ human chorionic gonadotropin (hCG; VeterinCorion, Divarsa, Barcelona, Spain), and 10\% porcine follicular fluid (v/v).

After microinjection, oocytes were cultured until embryo transfer in TALP medium (Rath et al. 1999) consisting of $114.1 \mathrm{mM} \mathrm{NaCl}, 3.2 \mathrm{mM} \mathrm{KCl}, 8 \mathrm{mM}$ Ca-lactate. $5 \mathrm{H}_{2} \mathrm{O}$, $0.5 \mathrm{mM} \quad \mathrm{MgCl}_{2} \cdot 6 \mathrm{H}_{2} \mathrm{O}, \quad 0.35 \mathrm{mM} \quad \mathrm{NaH}_{2} \mathrm{PO}_{4}, 25.1 \mathrm{mM}$ $\mathrm{NaHCO}_{3}, 10 \mathrm{ml} / \mathrm{l}$ Na-lactate, $1.1 \mathrm{mM}$ Na-pyruvate, $5 \mathrm{mM}$ glucose, $2 \mathrm{mM}$ caffeine, $3 \mathrm{mg} / \mathrm{ml}$ BSA (A-9647), $1 \mathrm{mg} / \mathrm{ml}$ polyvinyl alcohol (PVA), and $0.17 \mathrm{mM}$ kanamycin sulfate. The medium used for embryo micromanipulation was Dulbecco's PBS (DPBS) supplemented with 10\% FCS.

The embryo culture medium was NCSU-23 containing $0.4 \%$ BSA (A-8022), $75 \mu \mathrm{g} / \mathrm{ml}$ potassium penicillin $\mathrm{G}$, and $50 \mu \mathrm{g} / \mathrm{ml}$ streptomycin sulfate (Macháty et al. 1998).

Swine fertilization medium (SFM; Lavitrano et al. 2002) was used for processing the spermatozoa (SFM: 1 I contains glucose $11.25 \mathrm{~g}$, Na citrate $\left(2 \mathrm{H}_{2} \mathrm{O}\right) 10 \mathrm{~g}$, EDTA $\left(2 \mathrm{H}_{2} \mathrm{O}\right) 4.7 \mathrm{~g}$, citric acid $\left(\mathrm{H}_{2} \mathrm{O}\right) 3.25 \mathrm{~g}$, Trizma $6.5 \mathrm{~g}$ supplemented with $6 \mathrm{mg} / \mathrm{ml}$ BSA (SFM/BSA)).

\section{Methods}

\section{Transgene construction and PCR detection}

The EGFP plasmid construct (pEGFPN1, 5.4 kb; Clontech Laboratories, Inc.) used for our experiments contained the human CMV immediate early promoter and the enhanced GFP gene. This construct was linearized with Aflll prior to use. The transgene was purified using an Elu-Quit DNA Purification Kit (Schleicher \& Schuell, Dassel, Germany) following the manufacturer's instructions. DNA was resuspended in TE (10 mM Tris and $0.1 \mathrm{mM}$ EDTA, $\mathrm{pH}$ 8). 
Transgene presence was confirmed by EGFP PCR (Gutiérrez-Adán \& Pintado 2000). EGFP PCR was performed using the primers GFP-1 (5'-TGA ACC GCA TCG AGC TGA AGG G-3') and GFP-2 (5'-TCC AGC AGG ACC ATG TGA TCG C-3'), specifically amplifying a 340-bp portion of GFP DNA. DNA was extracted from different tissues of the piglets to analyze for the presence of the transgenic DNA. Amplification was carried out in a total volume of $25 \mu \mathrm{l}(1 \times$ of PCR mix containing $1 \mathrm{U}$ Taq polymerase, $2.5 \mu \mathrm{l} 10 \times$ buffer, both from Promega, $100 \mu \mathrm{M}$ each dNTP, $0.1 \mu \mathrm{M}$ each primer, and $2.5 \mathrm{mM} \mathrm{MgCl} 2$ ). Samples were loaded directly from ice onto the heating block at $92{ }^{\circ} \mathrm{C}$ to minimize the time required to reach denaturation temperature. The PCR protocol was an initial step of $92{ }^{\circ} \mathrm{C}$ (2 min), followed by 32 cycles of $92{ }^{\circ} \mathrm{C}$ $(30 \mathrm{~s}), 59^{\circ} \mathrm{C}(30 \mathrm{~s})$, and $72{ }^{\circ} \mathrm{C}(30 \mathrm{~s})$ and a final extension cycle at $72{ }^{\circ} \mathrm{C}$ (10 min). PCR products were resolved on $1.5 \%$ Tris/borate/EDTA agarose gels, followed by staining with ethidium bromide and visualized using u.v. light.

\section{Semen collection and preparation of sperm for DNA uptake}

Fresh semen was routinely collected from mature fertile boars ('Lo Navarro' S.A., Murcia, Spain) using the manual method and a dummy (King \& Macpherson 1973). The sperm-rich fraction was collected in a pre-warmed thermos flask, and the gel fraction was held on a gauze tissue covering the thermos opening.

Semen was prepared according to the method described by Lavitrano et al. (2002) and García-Vázquez et al. (2009). Spermatozoa $\left(10^{8}\right.$ cells $\left./ \mathrm{ml}\right)$ were incubated with transgene (pEGFP) or RecA:ssDNA linearized EGFP transgene complexes (5 or $15 \mu \mathrm{g} \mathrm{DNA} / \mathrm{ml}$ ) in SFM with BSA at $16^{\circ} \mathrm{C}$.

\section{Preparation of RecA:ssDNA complexes}

RecA:ssDNA complexes were prepared as described previously (Kaneko et al. 2005, Moreira et al. 2007). Denatured ssDNA was quenched on ice, and the appropriate quantity of RecA solution was added in order to satisfy a 40:1 or 40:3 protein:DNA (weight:weight) ratio, ensuring coating of all ssDNA and a final DNA concentration of 10 or $30 \mathrm{ng} / \mu \mathrm{l}$ respectively. The mixture was incubated in ice for $1 \mathrm{~h}$, and then mixed with fresh semen at $16{ }^{\circ} \mathrm{C}$ for $30 \mathrm{~min}$ for embryo production or $2 \mathrm{~h}$ for evaluation of sperm function.

\section{Sperm motility assessment using a computer-assisted analysis system}

Motion parameters were determined using a CASA system (Sperm Class Analyzer, Microptic, Barcelona, Spain). A 7- $\mu$ I drop of the sample was placed on a warmed $\left(37^{\circ} \mathrm{C}\right)$ slide and covered with a $24 \mathrm{~mm}^{2}$ cover slip. The setting parameters were 25 frames, in which spermatozoa had to be present in at least 15 in order to be counted. Images were obtained at $\times 200$ magnification with a phase microscope. Spermatozoa with VAP $<20 \mu \mathrm{m} / \mathrm{s}$ were considered as immotile. A minimum of five fields per sample was evaluated, counting a minimum of 200 spermatozoa per subsample. The CASA-derived motility characteristics measured were VCL $(\mathrm{mm} / \mathrm{s})$, straight-line velocity $(\mathrm{VSL}, \mathrm{mm} / \mathrm{s}), \operatorname{VAP}(\mathrm{mm} / \mathrm{s})$, linearity of the curvilinear trajectory (LIN, ratio of VSL/NCL, \%), straightness (STR, ratio of VSL/VAP, \%), amplitude of lateral head displacement $(\mathrm{ALH}, \mathrm{mm})$, and beat cross frequency $(\mathrm{BCF}, \mathrm{Hz})$.

\section{Analysis of seminal parameters by flow cytometry}

Flow cytometric analyses were performed on a Coulter Epics XL cytometer (Beckman Coulter Inc., Miami, FL, USA). A $15-\mathrm{mW}$ argon ion laser operating at $488 \mathrm{~nm}$ excited the fluorophores. Data from 10000 events per sample were collected in list mode, and four measures per sample were recorded. Flow cytometric data were analyzed using the program Expo32ADC (Beckman Coulter Inc.) using a gate in forward and side scatter to exclude eventual remaining debris and aggregates from the analysis.

Assessment of membrane lipid disorder. To detect the increase in plasma membrane lipid packing disorder, sperm samples were stained with merocyanine 540 (M540) and Yo-Pro 1 (Harrison et al. 1996). Stock solutions of M-540 (1 mM) and Yo-Pro 1 (25 $\mu \mathrm{M}$, Invitrogen S.A.) in DMSO were prepared. For each 1-ml diluted semen sample $\left(5-10 \times 10^{6}\right), 2.7-\mu l$ M540 stock solution was added (final concentration of $2.7 \mu \mathrm{M}$ ), and $1 \mu \mathrm{l}$ of Yo-Pro was added (25 nM final concentration). M 540 fluorescence was collected with a FL2 sensor using a 575-nm band-pass filter, and Yo-Pro 1 was collected with a FL-1 sensor using a 525-nm band-pass filter. Cells were classified as having low merocyanine fluorescence (viable and low disorder), high merocyanine fluorescence (viable and high disorder), or Yo-Pro-1 positive (dead).

Plasma membrane integrity. Seminal samples $(1 \mathrm{ml}$ of semen $5-10 \times 10^{6}$ spermatozoa) were incubated with $5 \mu$ l of PI stock solution $(500 \mu \mathrm{g})$ final solution $2.5 \mu \mathrm{g}$ at room temperature for $10 \mathrm{~min}$. PI fluorescence was collected with a FL2 sensor using a 575-nm band-pass filter.

Generation of ROS. Production of ROS was measured by incubating the diluted spermatozoa in TALP in the presence of $2^{\prime}, 7^{\prime}$-dichlorodihydrofluorescein diacetate $\left(\mathrm{H}_{2}\right.$ DCFDA $(0.5 \mu \mathrm{M}$; Gadea et al. 2005). This fluorogenic probe is commonly used to detect cellular ROS production. $\mathrm{H}_{2}$ DCFDA is a stable cell-permeable nonfluorescent dye that is de-esterified intracellularly, thus turning to highly fluorescent $2^{\prime}, 7^{\prime}$-dichlorofluorescin upon oxidation. In total, $10 \times 10^{6}$ cells $/ \mathrm{ml}$ were incubated for 60 min with $5 \mu \mathrm{l}$ from $\mathrm{H}_{2}$ DCFDA stock solution (final concentration $0.5 \mu \mathrm{M}$ ) before being measured by the flow cytometer. Green fluorescence was recorded with a FL1 sensor using a 525-nm band-pass filter. Measurements were expressed as the mean green intensity fluorescence units (mean channel in the FL1).

\section{Oocyte collection and in vitro maturation}

Within 30 min of slaughter, ovaries from prepuberal gilts were transported to the laboratory in saline $(0.9 \% \mathrm{w} / \mathrm{v} \mathrm{NaCl})$ containing $100 \mu \mathrm{g} / \mathrm{ml}$ kanamycin sulfate at $37^{\circ} \mathrm{C}$, and then washed once in $0.04 \%(\mathrm{w} / \mathrm{v})$ cetrimide solution and twice in saline. Oocyte-cumulus cell complexes (COCs) were collected from nonatretic follicles (3-6 mm diameter), and washed twice in 35-mm plastic Petri dishes containing DPBS supplemented 
with $4 \mathrm{mg} / \mathrm{ml}$ PVA. Groups of 50 COCs were cultured in 500- $\mu \mathrm{l}$ maturation medium for $20-22 \mathrm{~h}$ at $38.5^{\circ} \mathrm{C}$ under $5 \% \mathrm{CO}_{2}$ in air. Once cultured, the COCs were washed twice, transferred to fresh maturation medium without hormonal supplements or dibutyryl cAMP, and cultured for 20-22 h (Funahashi \& Day 1993).

\section{ICSI with the construct (EGFP)}

The spermatozoa were incubated with transgene (pEGFP) or RecA:ssDNA complexes at $16{ }^{\circ} \mathrm{C}$ for $30 \mathrm{~min}$, and then, the sperm samples were prewarmed at $38{ }^{\circ} \mathrm{C}$ for 5 min before ICSI. COCs cultured for $44 \mathrm{~h}$ in maturation medium were mechanically stripped of cumulus by gentle aspiration with a pipette. Denuded oocytes were washed two times in supplemented DPBS medium and transferred to ICSI drops. ICSI was performed as described by García-Roselló et al. (2006) and García-Vázquez et al. (2009).

\section{IVF and embryo culture}

COCs cultured for a total of $44 \mathrm{~h}$ in maturation medium were stripped of cumulus mechanically by gentle aspiration with a pipette. Oocytes were washed three times with TALP medium, and groups of 30-35 oocytes were transferred into each well of a four-well multidish containing $250 \mu \mathrm{l}$ of IVF medium previously equilibrated at $38.5{ }^{\circ} \mathrm{C}$ under $5 \% \mathrm{CO}_{2}$. The sperm suspension $(250 \mu \mathrm{l})$ was added to fertilization wells to obtain a final concentration of 3000 cells/oocyte. At 2-h post insemination (hpi), oocytes were washed twice with fresh NCSU-23 by gentle aspiration through a glass pipette and allowed to continue in culture at $38.5{ }^{\circ} \mathrm{C}$ under $5 \% \mathrm{CO}_{2}$.

After $2 \mathrm{~h}$ (in the case of IVF) and 20-24 $\mathrm{h}$ (in the case of ICSI), putative zygotes were washed three times in NCSU23 previously equilibrated overnight, transferred into microdrops at a rate of $5 \mu \mathrm{l}$ of NCSU-23 media/embryo and covered with mineral oil (embryo tested) in a Petri dish, and incubated at $38.5{ }^{\circ} \mathrm{C}$ and $5 \% \mathrm{CO}_{2}$ in $100 \%$ humidified air for 7 days.

\section{Microscopic embryo development evaluation}

After culture, the embryos were evaluated under a stereomicroscope, and a sample was fixed in absolute ethanol for $24 \mathrm{~h}$. After staining with Hoechst $33342(10 \mathrm{mg} / \mathrm{ml}$ in PBS), cell nuclei were counted under an epifluorescence microscope.

\section{Analysis of EGFP expression in embryos}

Expression in embryos was examined $144 \mathrm{~h}$ post fertilization. The embryos were examined by epifluorescence microscopy (Diaphot 300, Nikon, Tokyo, Japan) with FITC filters (excitation range of $395-470 \mathrm{~nm}$ and emission spectrum of $509 \mathrm{~nm}$ ). This enabled the clear identification of nonfluorescent (non-EGFP expressing) and fluorescent embryos (EGFP expressing), which were scored accordingly.

\section{Embryo transfer}

Estrus and superovulation in prepuberal crossbed recipient gilts were induced by i.m. administration 1250 IU of eCG (Folligon,
Intervet, Boxmeer, The Netherlands), followed after $72 \mathrm{~h}$ by 750 IU of hCG (Veterin Corion, Divisa Farmavic S.A., Barcelona, Spain). Preoperative anesthetic and analgesic induction of animals was carried out by a combination of ketamine $(100 \mathrm{mg} / \mathrm{ml}) 10 \mathrm{mg} / \mathrm{kg}$ (Imalgene 1000, Merial Laboratorios S.A., Barcelona, Spain), medetomidine $(1.0 \mathrm{mg} / \mathrm{ml}) 0.2 \mathrm{mg} / \mathrm{kg}$ (Domtor, Pfizer S.A., Madrid, Spain), midazolam ( $5 \mathrm{mg} / 5 \mathrm{ml}$ ) $0.2 \mathrm{mg} / \mathrm{kg}$ (Dormicum, Roche), and morphine hydrochloride $(20 \mathrm{mg} / \mathrm{ml}) \quad 0.2 \mathrm{mg} / \mathrm{kg}$ (Morphine Braun 2\%, B. Braun Medical S.A., Barcelona, Spain) administered i.m. The anesthetic level was maintained using isofluorane (Isoflo, Laboratorios Dr Esteve S.A., Barcelona, Spain) vaporized in oxygen at $2-3 \%$.

Oviducts from animals were exposed through a mid-ventral incision. Over 100 putative zygotes, produced by ICSI 2-3 $\mathrm{h}$ before surgery, were introduced into both oviducts $(\sim 50$ putative zygotes in each one) by a Tom Cat Catheter (Kendall Co., Mansfield, MA, USA). The sows were kept under the usual farm conditions, and 25-28 days after transfer, pregnancy diagnosis was carried out by ultrasonography (100 FALCO-VET scan, Esaote España S.A., Barcelona, Spain).

\section{Analysis of EGFP expression in piglets}

Direct observation. EGFP expression was evaluated by direct visualization of piglets through blue light with a maximum excitation of $488 \mathrm{~nm}$ by a lamp that emits u.v. light.

Western blotting. Proteins were extracted from different tissues of the piglets. Samples were dissolved in sample buffer in reducing ( $5 \% \quad \beta$-mercaptoethanol (vol/vol)) conditions. After boiling for $5 \mathrm{~min}$, samples were separated by $12 \%$ SDS/PAGE. In brief, $4 \%$ stacking and $12 \%$ separating gels were used and run using $25 \mathrm{mM}$ Tris/0.2 M glycine buffers, $\mathrm{pH}$ 8.6, containing $0.1 \%$ SDS for $1.5 \mathrm{~h}$ at $150 \mathrm{~V}$ at room temperature. For western blots, the SDS-PAGE slab gels were equilibrated for $30 \mathrm{~min}$ in $25 \mathrm{mM}$ Tris and $192 \mathrm{mM}$ glycine in $20 \%$ (vol/vol) methanol, and proteins were electrotransferred to PVDF membrane at $100 \mathrm{~V}$ for $1 \mathrm{~h}$.

The membrane was incubated in blocking buffer (TBST-BSA $5 \%$ ) for $1 \mathrm{~h}$, and later washed two times for $10 \mathrm{~min}$ with washing buffer (TBST) and rocked gently with primary antibody (rabbit polyclonal anti-GFP; Abcam, Cambridge, UK; 1:1000) for $1 \mathrm{~h}$, followed by incubation with secondary antibody (goat anti-rabbit IgG-HRP, Santa Cruz Biotechnology Inc., Santa Cruz, CA, USA; 1:20 000) for $1 \mathrm{~h}$. The detection procedure was carried out in a dark room using an ECL plus Kit (Amersham Pharmacia Biotech, Inc). The membranes were scanned using a Typhoon 9410 imager (Amersham Pharmacia Inc. Biotechnology, Bioscience) for detection of chemiluminescence.

To assess EGFP expression in tissues, SDS-PAGE and western blots were performed in putative transgenic animals as well as negative and positive control animals to verify further the EGFP expression. The positive control, for each one of the analyses, was made using EGFP transgenic mouse (29 kDa) or ZP3-GFP mouse $(82 \mathrm{kDa})$. The EGFP from our analysis has a molecular weight of $29 \mathrm{kDa}$. 


\section{Immunohistochemistry}

Samples of different tissues were fixed at $4{ }^{\circ} \mathrm{C}$ in $4 \%$ paraformaldehyde overnight, dehydrated, and embedded in paraplast wax (McCormick, Richmond, IL, USA). Sections $(5 \mu \mathrm{m})$ were placed on Superfrost Plus microscope slides (Menzel, Braunschweig, Germany). Slides were then deparaffined in xylene, rehydrated through a descending ethanol series, and washed in PBS.

The tissue sections were treated with proteinase $\mathrm{K}(10 \mu \mathrm{g} / \mathrm{ml})$ for $3 \mathrm{~min}$ and washed twice with PBS containing $0.1 \%$ Tween 20 (PBT). Then, endogenous peroxidase was blocked with $0.3 \%$ hydrogen peroxide in PBS, $\mathrm{pH} 7.2$. After that, the sections were blocked in PBS containing 1\% BSA for $1 \mathrm{~h}$ at room temperature and incubated in a moist chamber with Rabbit Polyclonal anti-GFP antibody (Abcam) (1:500). After washing in PBS, the sections were incubated with goat anti-rabbit IgG-HRP antibody (Santa Cruz Biotechnology Inc.; 1:4000). The staining was obtained using EnVision FLEX Mini Kit, High pH (Dako UK Ltd, Cambridge, UK). The sections were then counterstained with hematoxylin, dehydrated, cleared, and mounted in DPX. Images were collected with a Leica DM 6000 microscope joined to a digital camera (Leica DFC 280, Wetzlar, Germany) and Software Leica Application Suite.

\section{Statistical analysis}

Data are presented as means \pm S.E.M. and analyzed by ANOVA considering the specific sperm treatment as the main variable. When ANOVA revealed a significant effect, values were compared by the least significant difference pairwise multiple comparison post hoc test (Tukey). Differences were considered statistically significant at $P<0.05$. Cleavage and blastocyst data (categorical data) were modeled according to the binomial model of parameters by arcsine transformation of the data, and were analyzed by ANOVA.

\section{Declaration of interest}

The authors declare that there is no conflict of interest that could be perceived as prejudicing the impartiality of the research reported.

\section{Funding}

This work was supported by BIOCARM 10BIO/2005-01-6463, Fundación Séneca (08752/PI/08) and MEC-FEDER AGL200603495 and AGL2009-12512-C02-01.

\section{Acknowledgements}

The authors would like to acknowledge Dr John Parrington (University of Oxford) for critical reading of this manuscript. We would also like to thank S Rodriguez and J A Carvajal for their generous technical assistance; Ruth Tunn (University of Oxford) for help with the language in the manuscript; Lo Navarro farm for providing the boar semen and the animals necessary for this study; the staff of the slaughterhouse
'El Pozo' for supplying the ovaries, and we would also like to thank Minimally Invasive Surgery Center Jesús Usón (Cáceres, Spain) for their technical assistance in obtaining biopsy samples.

\section{References}

Abeydeera LR \& Day BN 1997 Fertilization and subsequent development in vitro of pig oocytes inseminated in a modified Tris-buffered medium with frozen-thawed ejaculated spermatozoa. Biology of Reproduction 57 729-734.

Alderson J, Wilson B, Laible G, Pfeffer P \& L'Huillier P 2006 Protamine sulfate protects exogenous DNA against nuclease degradation but is unable to improve the efficiency of bovine sperm mediated transgenesis. Animal Reproduction Science 91 23-30.

Anzar M \& Buhr MM 2006 Spontaneous uptake of exogenous DNA by bull spermatozoa. Theriogenology 65 683-690.

Bolling LC, Pleasant RS, Butler SP, Velander WH \& Gwazdauskas FC 2003 An evaluation of sperm-mediated gene transfer in the pig. Transgenics 4 77-86.

Brackett BG, Baranska W, Sawicki W \& Koprowski H 1971 Uptake of heterologous genome by mammalian spermatozoa and its transfer to ova through fertilization. PNAS 68 353-357.

Cabot RA, Kuhholzer B, Chan AW, Lai L, Park KW, Chong KY, Schatten G, Murphy CN, Abeydeera LR, Day BN et al. 2001 Transgenic pigs produced using in vitro matured oocytes infected with a retroviral vector. Animal Biotechnology 12 205-214.

Cazaux C, Blanchet JS, Dupuis D, Villani G, Defais M \& Johnson NP 1998 Investigation of the secondary DNA binding site of the bacterial recombinase RecA. Journal of Biological Chemistry 273 28799-28804.

Celebi C, Guillaudeux T, Auvray P, Vallet-Erdtmann V \& Jegou B 2003 The making of "transgenic spermatozoa". Biology of Reproduction $\mathbf{6 8}$ 1477-1483.

Chan PJ 2000 Sperm-mediated DNA transfer to cells of the uterus and embryo. Molecular Reproduction and Development 56 316-318.

Chan AW, Kukolj G, Skalka AM \& Bremel RD 1999 Timing of DNA integration, transgenic mosaicism, and pronuclear microinjection. Molecular Reproduction and Development 52 406-413.

Chan AW, Luetjens CM, Dominko T, Ramalho-Santos J, Simerly CR, Hewitson L \& Schatten G 2000a Foreign DNA transmission by ICSI: injection of spermatozoa bound with exogenous DNA results in embryonic GFP expression and live rhesus monkey births. Molecular Human Reproduction 6 26-33.

Chan AW, Luetjens CM, Dominko T, Ramalho-Santos J, Simerly CR, Hewitson L \& Schatten G 2000b Transgen-ICSI reviewed: foreign DNA transmission by intracytoplasmic sperm injection in rhesus monkey. Molecular Reproduction and Development 56 325-328.

Chow SA, Honigberg SM, Bainton RJ \& Radding CM 1986 Patterns of nuclease protection during strand exchange. RecA protein forms heteroduplex DNA by binding to strands of the same polarity. Journal of Biological Chemistry 261 6961-6971.

Coward K, Kubota H \& Parrington J 2007 In vivo gene transfer into testis and sperm: developments and future application. Archives of Andrology 53 187-197.

De Lamirande E, Jiang H, Zini A, Kodama H \& Gagnon C 1997 Reactive oxygen species and sperm physiology. Reviews of Reproduction 2 48-54.

Francolini M, Lavitrano M, Lamia CL, French D, Frati L, Cotelli F \& Spadafora C 1993 Evidence for nuclear internalization of exogenous DNA into mammalian sperm cells. Molecular Reproduction and Development 34 133-139.

Funahashi H \& Day BN 1993 Effects of follicular fluid at fertilization in vitro on sperm penetration in pig oocytes. Journal of Reproduction and Fertility 99 97-103.

Gadea J \& García-Vázquez FA 2010a Methodologies for generating transgenic pigs. ITEA-Informacion Tecnica Economica Agraria 106 15-29.

Gadea J \& García-Vázquez FA 2010b Applications of transgenic pigs in biomedicine and animal production. ITEA-Informacion Tecnica Economica Agraria 106 30-45. 
Gadea J, Gumbao D, Matás C \& Romar R 2005 Supplementation of the thawing media with reduced glutathione improves function and the in vitro fertilizing ability of boar spermatozoa after cryopreservation. Journal of Andrology 26 749-756.

Gagné MB, Pothier F \& Sirard MA 1991 Electroporation of bovine spermatozoa to carry foreign DNA in oocytes. Molecular Reproduction and Development 29 6-15.

García-Roselló E, Coy P, García-Vázquez FA, Ruiz S \& Matás C 2006 Analysis of different factors influencing the intracytoplasmic sperm injection (ICSI) yield in pigs. Theriogenology 6 1857-1865.

García-Roselló E, Garcia-Mengual E, Coy P, Alfonso J \& Silvestre M 2009 Intracytoplasmic sperm injection in livestock species: an update. Reproduction in Domestic Animals 44 143-151.

García-Vázquez FA, García-Roselló E, Gutiérrez-Adán A \& Gadea J 2009 Effect of sperm treatment on efficiency of EGFP-expressing porcine embryos produced by ICSI-SMGT. Theriogenology 72 506-518.

Garrick D, Fiering S, Martin DI \& Whitelaw E 1998 Repeat-induced gene silencing in mammals. Nature Genetics 18 56-59.

Gutiérrez-Adán A \& Pintado B 2000 Effect of flanking matrix attachment regions on the expression of microinjected transgenes during preimplantation development of mouse embryos. Transgenic Research 9 81-89.

Harrison RA 1997 Sperm plasma membrane characteristics and boar semen fertility. Journal of Reproduction and Fertility Supplement 52 195-211.

Harrison RA, Ashworth PJ \& Miller NG 1996 Bicarbonate/CO $\mathrm{CO}_{2}$ an effector of capacitation, induces a rapid and reversible change in the lipid architecture of boar sperm plasma membranes. Molecular Reproduction and Development 45 378-391.

Hewitson L, Dominko T, Takahashi D, Martinovich C, Ramalho-Santos J, Sutovsky P, Fanton J, Jacob D, Monteith D, Neuringer M et al. 1999 Unique checkpoints during the first cell cycle of fertilization after intracytoplasmic sperm injection in rhesus monkeys. Nature Medicine 5 431-433.

Hirabayashi M, Kato M, Ishikawa A, Kaneko R, Yagi T \& Hochi S 2005 Factors affecting production of transgenic rats by ICSI-mediated DNA transfer: effects of sonication and freeze-thawing of spermatozoa, rat strains for sperm and oocyte donors, and different constructs of exogenous DNA. Molecular Reproduction and Development 70 422-428.

Horan R, Powell R, Gannon F \& Houghton JA 1992 The fate of foreign DNA associated with pig sperm following the in vitro fertilization of zona-free hamster ova and zona-intact pig ova. Archives of Andrology 29 199-206.

Hyttel P, Viuff D, Laurincik J, Schmidt M, Thomsen PD, Avery B, Callesen H, Rath D, Niemann H, Rosenkranz C et al. 2000 Risks of in-vitro production of cattle and swine embryos: aberrations in chromosome numbers, ribosomal RNA gene activation and perinatal physiology. Human Reproduction 5 87-97.

Kaneko T, Moisyadi S, Suganuma R, Hohn B, Yanagimachi R \& Pelczar P 2005 Recombinase-mediated mouse transgenesis by intracytoplasmic sperm injection. Theriogenology 64 1704-1715.

Kang JH, Hakimov H, Ruiz A, Friendship RM, Buhr M \& Golovan SP 2008 The negative effects of exogenous DNA binding on porcine spermatozoa are caused by removal of seminal fluid. Theriogenology 70 1288-1296.

King GJ \& Macpherson JW 1973 A comparison of two methods for boar semen collection. Journal of Animal Science 36 563-565.

Kowalczykowski SC \& Eggleston AK 1994 Homologous pairing and DNA strand-exchange proteins. Annual Reviews of Biochemistry 63 991-1043.

Kurome M, Ueda H, Tomii R, Naruse K \& Nagashima H 2006 Production of transgenic-clone pigs by the combination of ICSI-mediated gene transfer with somatic cell nuclear transfer. Transgenic Research 15 229-240.

Lai L, Sun Q, Wu G, Murphy CN, Kuhholzer B, Park KW, Bonk AJ, Day BN \& Prather RS 2001 Development of porcine embryos and offspring after intracytoplasmic sperm injection with liposome transfected or non-transfected sperm into in vitro matured oocytes. Zygote 9 339-346.

Lai L, Kolber-Simonds D, Park KW, Cheong HT, Greenstein JL, Im GS, Samuel M, Bonk A, Rieke A, Day BN et al. 2002 Production of alpha-1,3galactosyltransferase knockout pigs by nuclear transfer cloning. Science 295 1089-1092.
Lanes CFC, Sampaio LA \& Marins LF 2009 Evaluation of DNase activity in seminal plasma and uptake of exogenous DNA by spermatozoa of the Brazilian flounder Paralichthys orbignyanus. Theriogenology $\mathbf{7 1}$ 525-533.

Lavitrano M, Camaioni A, Fazio VM, Dolci S, Farace MG \& Spadafora C 1989 Sperm cells as vectors for introducing foreign DNA into eggs: genetic transformation of mice. Cell 57 717-723.

Lavitrano M, Forni M, Varzi V, Pucci L, Bacci ML, Di Stefano C, Fioretti D, Zoraqi G, Moioli B, Rossi M et al. 1997 Sperm-mediated gene transfer: production of pigs transgenic for a human regulator of complement activation. Transplantation Proceedings 29 3508-3509.

Lavitrano M, Bacci ML, Forni M, Lazzereschi D, Di Stefano C, Fioretti D, Giancotti P, Marfe G, Pucci L, Renzi L et al. 2002 Efficient production by sperm-mediated gene transfer of human decay accelerating factor (hDAF) transgenic pigs for xenotransplantation. PNAS 99 14230-14235.

Macháty Z, Day BN \& Prather RS 1998 Development of early porcine embryos in vitro and in vivo. Biology of Reproduction $\mathbf{5 9}$ 451-455.

Maga EA 2001 The use of recombinase proteins to generate transgenic large animals. Cloning Stem Cells 3 233-241.

Maga EA, Sargent RG, Zeng H, Pati S, Zarling DA, Oppenheim SM, Collette NM, Moyer AL, Conrad-Brink JS, Rowe JD et al. 2003 Increased efficiency of transgenic livestock production. Transgenic Research 12 485-496.

Maione B, Pittoggi C, Achene L, Lorenzini R \& Spadafora C 1997 Activation of endogenous nucleases in mature sperm cells upon interaction with exogenous DNA. DNA and Cell Biology 16 1087-1097.

Moreira PN, Giraldo P, Cozar P, Pozueta J, Jiménez A, Montoliu L \& Gutiérrez-Adán A 2004 Efficient generation of transgenic mice with intact yeast artificial chromosomes by intracytoplasmic sperm injection. Biology of Reproduction 71 1943-1947.

Moreira PN, Perez-Crespo M, Ramirez MA, Pozueta J, Montoliu L \& Gutierrez-Adán A 2007 Effect of transgene concentration, flanking matrix attachment regions, and RecA-coating on the efficiency of mouse transgenesis mediated by intracytoplasmic sperm injection. Biology of Reproduction 76 336-343.

Myles DG \& Primakoff P 1997 Why did the sperm cross the cumulus? To get to the oocyte. Functions of the sperm surface proteins $\mathrm{PH}-20$ and fertilin in arriving at, and fusing with, the egg Biology of Reproduction $\mathbf{5 6}$ 320-327.

Nakanishi T, Kuroiwa A, Yamada S, Isotani A, Yamashita A, Tairaka A, Hayashi T, Takagi T, Ikawa M, Matsuda Y et al. 2002 FISH analysis of 142 EGFP transgene integration sites into the mouse genome. Genomics $\mathbf{8 0}$ 564-574.

Naruse K, Ishikawa H, Kawano HO, Ueda H, Kurome M, Miyazaki K, Endo M, Sawasaki T, Nagashima H \& Makuuchi M 2005 Production of a transgenic pig expressing human albumin and enhanced green fluorescent protein. Journal of Reproduction and Development $\mathbf{5 1}$ 539-546.

Niemann H \& Kues WA 2000 Transgenic livestock: premises and promises. Animal Reproduction Science 60-61 277-293.

Niemann H, Rath D \& Wrenzycki C 2003 Advances in biotechnology: new tools in future pig production for agriculture and biomedicine. Reproduction in Domestic Animals 38 82-89.

Pereyra-Bonnet F, Fernández-Martín R, Olivera R, Jarazo J, Vichera G, Gibbons A \& Salamone D 2008 A unique method to produce transgenic embryos in ovine, porcine, feline, bovine and equine species. Reproduction, Fertility, and Development 20 741-749.

Perry AC, Wakayama T, Kishikawa H, Kasai T, Okabe M, Toyoda Y \& Yanagimachi R 1999 Mammalian transgenesis by intracytoplasmic sperm injection. Science 284 1180-1183.

Petters RM \& Sommer JR 2000 Transgenic animals as models for human disease. Transgenic Research 9 347-351.

Prather RS, Hawley RJ, Carter DB, Lai L \& Greenstein JL 2003 Transgenic swine for biomedicine and agriculture. Theriogenology $\mathbf{5 9}$ 115-123.

Rath D, Long CR, Dobrinsky JR, Welch GR, Schreier LL \& Johnson LA 1999 In vitro production of sexed embryos for gender preselection: high-speed sorting of X-chromosome-bearing sperm to produce pigs after embryo transfer. Journal of Animal Science 77 3346-3352. 
Rieth A, Pothier F \& Sirard MA 2000 Electroporation of bovine spermatozoa to carry DNA containing highly repetitive sequences into oocytes and detection of homologous recombination events. Molecular Reproduction and Development 57 338-345.

Shinohara A \& Ogawa T 1995 Homologous recombination and the roles of double-strand breaks. Trends in Biochemical Science 20 387-391.

Shinohara ET, Kaminski JM, Segal DJ, Pelczar P, Kolhe R, Ryan T, Coates CJ, Fraser MJ, Handler AM, Yanagimachi R et al. 2007 Active integration: new strategies for transgenesis. Transgenic Research 16 333-339.

Smith K \& Spadafora C 2005 Sperm-mediated gene transfer: applications and implications. BioEssays 27 551-562.

Spadafora C 1998 Sperm cells and foreign DNA: a controversial relation. BioEssays 20 955-964.

Sperandio S, Lulli V, Bacci ML, Forni M, Maione B, Spadafora C \& Lavitrano M 1996 Sperm mediated gene transfer in bovine and swine species. Animal Biotechnology 7 59-77.

Stein KK, Primakoff P \& Myles D 2004 Sperm-egg fusion: events at the plasma membrane. Journal of Cell Science 117 6269-6274.

Suganuma R, Pelczar P, Spetz JF, Hohn B, Yanagimachi R \& Moisyadi S 2005 Tn5 transposase-mediated mouse transgenesis. Biology of Reproduction 73 1157-1163.

Szczygiel MA, Moisyadi S \& Ward WS 2003 Expression of foreign DNA is associated with paternal chromosome degradation in intracytoplasmic sperm injection-mediated transgenesis in the mouse. Biology of Reproduction 68 1903-1910.

Terada Y, Luetjens CM, Sutovsky P \& Schatten G 2000 Atypical decondensation of the sperm nucleus, delayed replication of the male genome, and sex chromosome positioning following intracytoplasmic human sperm injection (ICSI) into golden hamster eggs: does ICSI itself introduce chromosomal anomalies? Fertility and Sterility $\mathbf{7 4}$ 454-460.
Twigg J, Fulton N, Gomez E, Irvine DS \& Aitken RJ 1998 Analysis of the impact of intracellular reactive oxygen species generation on the structural and functional integrity of human spermatozoa: lipid peroxidation DNA fragmentation and effectiveness of antioxidants. Human Reproduction 13 1429-1436.

Valentine L 2003 Agrobacterium tumefaciens and the plant: the David and Goliath of modern genetics. Plant Physiology 133 948-955.

Wall RJ 2002 New gene transfer methods. Theriogenology 57 189-201.

Whitelaw CB, Radcliffe PA, Ritchie WA, Carlisle A, Ellard FM, Pena RN, Rowe J, Clark AJ, King TJ \& Mitrophanous KA 2004 Efficient generation of transgenic pigs using equine infectious anaemia virus (EIAV) derived vector. FEBS Letters $\mathbf{5 7 1} 233-236$.

Wu Y, Liu CJ, Wan PC, Hao ZD \& Zeng SM 2009 Factors affecting the efficiency of producing porcine embryos expressing enhanced green fluorescence protein by ICSI-mediated gene transfer method. Animal Reproduction Science 113 156-166.

Yong HY, Hao Y, Lai L, Li R, Murphy CN, Rieke A, Wax D, Samuel M \& Prather RS 2006 Production of a transgenic piglet by a sperm injection technique in which no chemical or physical treatments were used for oocytes or sperm. Molecular Reproduction and Development73 595-599.

Zani M, Lavitrano M, French D, Lulli V, Maione B, Sperandio S \& Spadafora C 1995 The mechanism of binding of exogenous DNA to sperm cells: factors controlling the DNA uptake. Experimental Cell Research 217 57-64.

Received 9 March 2010

First decision 28 April 2010

Accepted 24 May 2010 